Alignment: Journal of Administration and Educational Management

Volume 1, Nomor 1, Juni 2018

e-ISSN : 2598-5159

p-ISSN : 2598-0742

DOI : https://doi.org/10.31539/alignment.v1i1.220

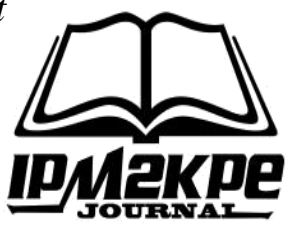

\title{
KEPEMIMPINAN WANITA SEBAGAI KEPALA SEKOLAH STUDI DI SDNEGERI KECAMATAN BALUNG KABUPATEN JEMBER
}

\author{
Selasi Priatiningsih \\ Institut Keguruan dan Ilmu Pendidikan, PGRI Jember \\ selasicezzi26@gmail.com
}

\begin{abstract}
ABSTRAK
Penelitian ini bertujuan untuk mendeskripsikan tipe kepemimpinan kepala sekolah perempuan serta persepsi guru terhadap gaya kepemimpinan kepala sekolah perempuan di Sekolah Dasar (SD) Negeri di Kecamatan Balung. Pendekatan yang digunakan yaitu pendekatan kuantitatif dengan metode survey untuk mendapatkan gambaran umum tipe dan gaya kepemimpinan para sekolah perempuan. Pengumpulan data dilakukan dengan teknik kuisioner dan wawancara terhadap 54 guru yang ada di 5 SD Negeri yang dikepalai oleh kepala sekolah perempuan. Teknik sampling menggunakan sampling jenuh dengan menggunakan seluruh populasi dari 5 sekolah. Hasil penelitian menunjukkan tipe dominan dari 5 kepala sekolah perempuan termasuk kedalam tipe kepemimpinan pribadi dengan mean 10.148 (SD 1.393) sedangkan tipe otoriter memperoleh nilai terkecil menjadi tipe minor yang dipilih guru dengan mean 9.056 (1.224). Sedangkan persepsi guru menunjukkan bahwa gaya kepemimpinan kepala sekolah di SD Negeri Kecamatan Balung cenderung feminin dengan mean 3.68 dan transformasional dengan mean 3.11yang juga didukung oleh dua indikator dari gaya maskulin dan transaksional. Simpulan, tipe dominan dari kepemimpinan kepala sekolah perempuan yang 'pribadi' serta gaya kepemimpinan yang 'feminin' dan 'transformasional'.
\end{abstract}

Kata Kunci: Kepemimpinan Wanita, Kepala Sekolah Wanita, Sekolah Dasar Balung

\section{ABSTRACT}

This study aims to describe the type of leadership of female principals and teacher perceptions of the leadership style of female principals in State Primary Schools in Balung District. The approach used is a quantitative approach with a survey method to get an overview of the types and styles of leadership of girls' schools. Data collection was carried out using questionnaire techniques and interviews with 54 teachers in 5 public elementary schools headed by female principals. The sampling technique uses saturated sampling using the entire population of 5 schools. The results showed the dominant type of 5 female principals included in the type of personal leadership with a mean of 10,148 (SD 1,393) while the authoritarian type obtained the smallest value to be the minor type chosen by teachers with a mean of 9,056 (1,224). While the teacher's perception shows that the principal's leadership style in SD Negeri Balung District tends to be feminine with a mean of 3.68 and transformational with a mean of 3.11 which is also supported by two indicators of 
masculine and transactional styles. Conclusions, the dominant type of female headmaster's leadership is 'personal' and 'feminine' and 'transformational' leadership styles.

Keywords: Women's Leadership, Women's Principal, Balung Elementary School

\section{PENDAHULUAN}

Wanita sering diidentikkan dengan kelembutan dan kelemahan.Oleh sebab itu, diskriminasi sering terjadi karena wanita dianggap tidak lebih mampu melakukan halhal yang bisa dikerjakan oleh laki-laki. Melihat kondisi wanita yang sering direndahkan harkat dan martabatnya, muncullah apa yang disebut emansipasi wanita. Hal ini tentu saja tidak bisa dipisahkan dari jasa seorang R.A. Kartini yang bergerak menerobos dinding pemisah antara hak wanita dan laki-laki. Beliau secara nyata berusaha menyetarakan hak-hak wanita pada masanya. Pada masa sekarang, para wanita mulai menunjukkan kemampuannya dengan pergerakan-pergerakan wanita yang menetang penjajahan atas diri mereka. Beberapa contoh perkumpulan wanita seperti Gerwani (Gerakan Wanita Indonesia) dan Lekra (Lembaga Kebudayaan Rakyat) merupakan gerakan wanita yang memiliki api perjuangan Kartini pada tahun 1960an (Nathan, 2017).

Para wanita pada masa sekarang lebih bebas mengekspresikan diri mereka terlebih lagi dalam ranah-ranah penting seperti Pendidikan. Para wanitaaktif menjadi tenaga pengajar, staf pengajaran bahkan mengepalai instansi tertentu (Syuqqah, 1997). Telah banyak posisi kepala sekolah yang diduduki oleh para wanita hebat. Banyak juga dari mereka sukses menjalani tugas sebagai seorang kepala yang membawa sekolah mereka kepada prestasi-prestasi membanggakan.

Posisi dibidang kepemimpinan akademis saat ini akan lebih mudah dikejar oleh wanita karena adanya persamaan hak untuk menempuh Pendidikan tinggi. Prestasi yang dicapai oleh mereka juga mendapat pengakuan dari masyarakat. Tidak ada lagi pembedaan kepemimpinan instansi. Terlebih lagi Indonesia yang pernah dipimpin oleh presiden wanita pertama yaitu Megawati Soekarno Putri. Contoh ini pastilah sangat berpengaruh besar dalam masyarakat akan pandangannya terhadap kaum wanita untuk menjadi pemimpin.

Lebih jauh lagi, mengepalai instansi Pendidikan seperti sebuah sekolah tentunya bukan hal yang mudah untuk dijalani. Kepala sekolah memiliki banyak tugas yang menaungi para pendidik, staf kependidikan serta siswa yang tidak sedikit jumlahnya. Seperti diketahui kepala sekolah memiliki beberapa tugas meliputi mempengaruhi, mendorong, membimbing serta menggerakkan guru, staf, siswa, orang tua siswa, masyarakat serta stakeholder (Murniati, 2008). Kepala sekolah memiliki peran sebagai konseptor yang melakukan penyusunan, peaksanaan dan tindak lanjut misi sekolah; sebagai manajer yang mengakomodir kepentingan tiap- 
tiapkelompok; menanamkan nilai-nilai kebenaran yang dijadikan landasan dalam rangka mewujudkan visi (Jelantik, 2012).

Namun, masih saja kepemimpinan wanita di Indonesia dipandang sebelah mata. Lagi-lagi pembuktian hasil kerjalah yang akan berbicara dan menepis segala pandangan buruk kepada kepemimpinan wanita. Pemberdayaan wanita juga sudah tidak sesuai lagi dengan kenyataan banyaknya kegiatan yang dilakukan oleh wanita. Hal yang lebih sesuai adalah peningkatan keberdayaan wanita (Suratman, 2017).

Kepemimpinan kepala sekolah wanita dalam manajemen kependidikan secara umum ternyata mampu mewujudkan kepemimpinan yang efektif karena wanita mempunyai keunggulan dalam memerankan dan menciptakan efektivitas organisasi, seperti pewujudan prestasi sekolah, terciptanya hubungan kekerabatan serta dapat memberdayakan anggotanya dan juga menekankan struktur organisasi dengan menekankan kerjasama tim, kepercayaan, fleksibelitas dan kemauan berbagi informasi (Halihah, 2015).

Namun, kepemimpinan pun dapat juga berbeda tergantung pada situasi dan kondisi tertentu. Oleh karena itu, sangat penting untuk menginvestigasi berbagai jenis, gaya dan bentuk kepemimpinan kepala sekolah wanita, contohnya di jenjang pendidikan yang berbeda pula. Dalam hal ini, persepsi para guru dianggap penting untuk memberikan pendapat dan penilaian akan hal tersebut. Studi ini bertujuan untuk menjelaskan kepemimpinan kepala sekolah wanita dalam manajemen pendidikan sekolah dasar di kecamatan Balung.

\section{METODE PENELITIAN}

Penelitian ini menerapkan pendekatan kuantitatif untuk memperoleh data yang berasal dari para guru di lima SD Negeri Kecamatan Balung yang dikelalai oleh kepala sekolah perempuan. Sampel yang didapat yaitu melalui sampling jenuh yaitu dengan mengambil semua jumlah populasi sebagai sample dengan margin of error 5 \% dengan jumlah sample (n) sebanyak 54 orang guru yang tersebar pada 5 SD Negeri yang dipimpin oleh kepala sekolah perempuan. SDN Balung Lor 01 dengan jumlah guru 12 orang, SDN Balung Lor 039 orang, SDN Balung Lor 0411 orang, SDN Balung Lor 0512 orang dan SDN Balung Lor 0610 orang.

Pengumpulan data dilakukan dengan menggunakan instrument berupa kuisioner yang akan disebar kepada para guru. Selanjutnya Teknik wawancara juga akan dilakukan untuk mendukung data yang berasal dari kusioner dan dilakukan untuk memperoleh dari kepala skeolah dan para guru. Dokumentasi dilakukan juga untuk memperoleh data berupa informasi yang terdokumentasi sebagai arsip.

Selanjutnya data dianalisis melalui tahapan identifikasi, transkripsi wawancara, perhitungan kuisioner, dan analisis dokumen. Untuk hasil kuesioner, dilakukan perhitungan dengan menggunakan Likert Scale dengan limapilihan jawaban dengan 
skala 1-5 dengan pilihan berupa TidakPernah (TP), Jarang (J), Sering (S), Sangat Sering (SS) dan Selalu (SL).

\section{HASIL DAN PEMBAHASAN}

Berdasarkan analisis data melalui prosedur statistik yang didukung oleh data wawancara terhadap 54 orang guru di 5 SD Negeri Balung Lor Kecamatan Balung, terlihat bahwa tipe dan juga gaya kepemimpinan kepala sekolah perempuan adalah sebagai berikut:

\section{Tipe Kepemimpinan Kepala Sekolah Perempuan}

Tipe kepemimpinan diketahui melalui penyebarang kuisioner terhadap 54 guru di 5 SD Negeri Kecamatan Balung yang dipimpin oleh kepala sekolah perempuan serta melalui hasil wawancara terhadap 15 guru perwakilan dari 5 SD tersebut.

Hanya 5 tipe kepemimpinan dari G. R. Terry yang terkandung dalam 15 kuisioner yaitu kepemimpinan pribadi, non pribadi, otoriter, demokratis dan paternalistis. Kepemimpinan berdasarkan bakat tidak diikutsertakan karena tipe ini merupakan tipe kepemimpinan dimana seseorang sebagai penggagas munculnya organisasi informal.Sedangkan Sekolah Dasar Negeri adalah organisasi berasal dari pemerintah.

Tabel 1

Tipe Kepemimpinan Kepala Sekolah Perempuan

\begin{tabular}{lcc}
\hline \multicolumn{1}{c}{ Tipe Kepemimpinan } & Mean & Deviasi Standar \\
\hline Kepemimpinan Pribadi & 10.148 & 1.393 \\
\hline Kepemimpinan Paternalistis & 10.056 & 1.381 \\
\hline Kepemimpinan Demokratis & 10 & 1.374 \\
\hline Kepemimpinan Non-Pribadi & 9.852 & 1.353 \\
\hline Kepemimpinan Otoriter & 9.056 & 1.244 \\
\hline
\end{tabular}

Terlihat dari perhitungan maka rata-rata kepemimpinan kepala sekolah perempuan di SD Negeri Kecamatan Balung mayoritas bersifat pribadi yaitu nilai tertinggi dengan mean 10.148 (SD 1.393). Pada kepemimpinan ini, kepala sekolah melakukan tindakan-tindakan dengan mengadakan kontak pribadi baik secara lisan atau langsung yang dilakukan oleh pemimpin seperti halnya mengundang rapat, meminta bantuan, dan menyampaikan pesan. Hal ini sesuai dengan karakter perempuan yang lebih mementingkan perasaan dari pada logika. Dan tipe ini seiring dengan tipe kepemimpinan paternalis yang bersifat keibuan dalam melakukan tindakan. Tipe ini merupakan tipe dengan skor tertinggi kedua setelah tipe pribadi yaitu dengan mean 10.057 (SD 1.381) dinilai dari perhitungan kuesioner para guru. Tipe ini dianggap sebagai sosok yang dapat mengayomi serta bijaksana dalam 
bersikap terutama disaat timbulnya masalah yang membutuhkan solusi. Keakraban juga terlihat antara hubungan kepala sekolah dan para guru.

Selanjutnya tipe demokratis menempati urutan ke 4 dan non-pribadi kelima. Dapat disimpulkan bahwa tipe kepemimpinan kepala sekolah yang masih memiliki sifat demokratis dengan mean 10 (1.374) seperti mendengarkan masukan, kritik dan saran. Tipe ini juga menunjukkan bahwa kepala sekolah masih bersama-sama dengan para guru untuk menyelesaikan permasalahan bersama-sama.

Tipe kepemimpinan otoriter yang menempati posisi terakhir menunjukkan bahwa meskipun masih ada sifat otoriter namun kepala sekolah tidak bersifat otoriter sepenuhnya melainkan lebih menekankan pada peraturan untuk menegakkan kedisiplinan di sekolah.

\section{Gaya Kepemimpinan Kepala Sekolah Perempuan}

Untuk menjawab pertanyaaan penelitian kedua, kuesioner kedua juga didistribusikan kepada 54 guru yang sama. Mereka diharuskan memberikan nilai pada setiap pernyataan dengan memilih kriteria Tidak Pernah (TP), Jarang (J), Sering (S), Selalu (SL) dan Sangat Sering (SS) dengan range skor 1-5.

Hasil yang diperoleh dari analisis data menunjukkan gaya kepemimpinan kepala sekolah perempuan tidak hanya menunjukkan gaya feminin saja tetapi juga ada beberapa sikap maskulin yang juga ditunjukkan. Secara umum hasil analisis data terlihat dalam table dibawah.

Tabel 2

Gaya Kepemimpinan Kepala Sekolah Perempuan berdasarkan Femininitas dan Maskulinitas

\begin{tabular}{clcl}
\hline No & Gaya Kepemimpinan & Mean & \multicolumn{1}{c}{ Kategori } \\
\hline $1 \quad$ Maskulin & & \\
\hline Agresif & 1,24 & Ada sedikit kecenderungan \\
\hline Kompetitif & 1,85 & Ada sedikit kecenderungan \\
\hline Yakin akan kemampuan diri & 2,63 & Ada sedikit kecenderungan \\
\hline Pengambil keputusan & 4,03 & Cenderung \\
\hline Rata-rata & 2,44 & Ada sedikit kecenderungan \\
\hline Feminin & & \\
\hline Simpatik & 4,85 & Sangat cenderung \\
\hline Lembut & 4,06 & Cenderung \\
\hline Pemalu & 1,14 & Ada sedikit kecenderungan \\
\hline Sensitif terhadap kebutuhan orang lain & 4,65 & Sangat cenderung \\
\hline Rata-rata & 3,68 & Cenderung \\
\hline
\end{tabular}

Kecenderungan gaya kepemimpinan berdasarkan femininitas dan maskulinitas kepala sekolah perempuan di SD Negeri di Kecamatan Balung menunjukkan kecenderungan gaya kepemimpinan feminin sesuai dengan gender kepala sekolah 
sebagai perempuan yaitu dengan mean 3,68. Gaya feminine yang dominan adalah simpatik dengan mean 4,85 yang ditunjukkan dengan sikap seperti simpatik terhadap permasalahan siswa, guru dan staf.

Kecenderungan kedua yang juga menunjukkan karakter perempuan yaitu sensitive terhadap kebutuhan orang lain yang ditunjukkan dengan sikap seperti jika para guru sedang melakukan kegiatan sekolah misalnya melatih siswa untuk persiapan lomba maka kepala sekolah akan berusaha memenuhi kebutuhan yang diperlukan baik berupa materi atau dukungan moral.

Gaya kepemimpinan feminism selanjutnya yaitu sikap lembut. Sesuai dengan karakter perempuan yang santun, lemah lembut dan sopan dalam bertutur dan bersikap juga ditunjukkan oleh gaya kepemimpinan kepala sekolah perempuan di SD Negeri Kecamatan Balung. Meskipun begitu angka yang ditunjukkan bukanlah angka yang mendominasi yaitu hanya 4,06 namun masih memiliki kriteria 'cenderung'.

Selanjutnya adalah sikap pemalu ditunjukkan dengan kriteria 'ada sedikit kecenderungan' dengan mean 1,14 yang berarti kepala sekolah perempuan di SD Negeri Kecamatan Balung tidak terlalu pemalu dalam bertugas sebagai pemimpin. Mereka lebih banyak menunjukkan sikap terbuka kepada staf dan guru di sekolah.Para guru menyatakan bahwa sikap pemalu akan terlihat kadangkala ketika mereka berhadapan dengan pihak luar sekolah. Sikap pemalu tidak terlalu ditunjukkan sebagai gaya karena tugas mereka yang berperan sebagai pemimpin memanglah dituntut untuk selalu terbuka dan juga tegas dalam bersikap.

Namun begitu berdasarkan analisis item, ternyata salah satu sikap dalam gaya maskulin juga dimiliki oleh kepala sekolah perempuan yaitu sebagai pengambil keputusan dengan kategori 'cenderung' ditunjukkan dengan mean 4,03. Hal ini ditunjukkan pada saat berlangsungnya rapat yang bersifat mendadak atau dalam rapat bulanan sekolah. Selanjutnya yaitu gaya kepemimpinan kepala sekolah perempuan yang termasuk gaya transformasional dan transaksional akan terlihat dari gambaran umu pada tabel dibawah.

Tabel 3

Gaya Kepemimpinan Kepala Sekolah Perempuan berdasarkan Gaya Transformasional dan Transaksional

\begin{tabular}{clcc}
\hline No & \multicolumn{1}{c}{ Gaya Kepemimpinan } & Mean & Kategori \\
\hline 1 & Transformasional & & \\
\hline Karisma & 2,89 & Ada sedikit kecenderungan \\
\hline Inspirasional & 2,36 & Ada sedikit kecenderungan \\
\hline Stimulasi intelektual & 3,08 & Ada sedikit kecenderungan \\
\hline Perhatian individual & 4,12 & Cenderung \\
\hline Rata-rata & 3.11 & Cenderung \\
\hline
\end{tabular}




\begin{tabular}{llcc}
\hline 2 & Transaksional & & \\
\hline Penugasan kerja & 2,65 & Ada sedikit kecenderungan \\
\hline Penghargaan kerja & 2,05 & Ada sedikit kecenderungan \\
\hline Tanggungjawab & 3,78 & Cenderung \\
\hline Rata-rata & 2.83 & Ada sedikit kecenderungan \\
\hline
\end{tabular}

Berdasarkan analisis data kepemimpinan kepala sekolah wanita cenderung memiliki gaya transformasional yang memang dinyatakan lebih unggul dari gaya transaksional (Robbins, Judge (2008). Kedua gaya salingmelengkapi satu sama lain karena memiliki nilai positif masing-masing tergantung kebutuhan. Namun berdasarkan kuisioner, persepsi para guru menyatakan bahwa hanya sedikit perbedaan antara gaya kepemimpinan transformasional dan transaksional yaitu dengan selisih 0.28 skor saja dari masing-masing mean 3.11 (transformasional) dan 2.83 (transaksional).

Ada 5 indikator untuk mengukur persepsi para guru tentang kecenderungan kepemimpinan transformasional yaitu berupa karisma, inspirasional, stimulasi intelektual dan perhatian individual (Timotius, 2016). Indikator tertinggi di tunjukkan oleh sikap perhatian individual dengan mean 4.12 pada kategori 'cenderung'. Dalam hal ini kepala sekolah sering memberikan perhatian secara individual lebih kepada bentuk perhatian orang per orangan, contohnya pada kesulitan yang dialami oleh guru yang bentuknya pribadi berupa musibah.

Untuk ketiga indikator lainnya berada pada kategori yang sama yaitu 'ada sedikit kecenderungan' meskipun skor yang diperoleh berbeda berdasarkan perhitungan mean. Masing-masing yaitu karisma, inspirasional dan stimulasi intelektual menunjukkan hanya sedikit kecenderungan sikap yang ditunjukkan dari persepsi para guru. Stimulasi intelektual merupakan suatu hal yang dapat menstimulus atau merangsang atau menggerakkan para guru secara intelektual dengan kemapuan akademis yang menonjol. Persepsi para guru mengenai hal ini dinilai dengan mean 3.08 dimana hal ini tidak begitu terlihat. Karisma berhubungan dengan kualitas pribadi individu yang membuat orang lain kagum dan memuja atas dirinya. Sedangkan rata-rata karisma yang dinilai dari persepsi para guru yaitu dengan mean 2.89 yang berarti hanya sedikit rasa kagum.

Indikator selanjutnya yaitu inspirasional yang berarti seorang kepala sekolah yang dapat meninspirasi dan mengilhami para guru dengan menunjukkan sikap dan prestasi yang dapat membuat mereka ingin melakukan hal serupa. Persepsi guru menunjukkan sikap inspirasional dengan mean 2.36 dengan kategori 'ada sedikit kecenderungan'. Kecenderungan yang kurang pada indikator ini yaitu kurangnya sikap dan prestasi kepala sekolah yang membuat para guru kagum yang cenderung menunjukkan kurangnya kreativitas dan inovasi kepala sekolah dalam melakukan hal baru. 
Gaya kedua yaitu gaya kepemimpinan transaksional yang diukur dari 3 indikatorberupa penugasan kerja yang jelas, penghargaan kerja dan tanggungjawab dengan mean 2.83. Angka ini lebih kecil dari gaya transformasional namun tetap menunjukkan kategori 'ada sedikit kecenderungan' yang berarti bahwa sikap ini terdapat pada gaya kepemimpinan kepala sekolah perempuan di SD Negeri Kecamatan Balung. Meskipun begitu indikator tanggungjawab muncul sebagai angka persepsi tertinggi dengan mean 3.78 dengan kategori 'cenderung'. Menurut para guru, kepala sekolah cenderung menunjukkan sikap bertanggungjawab terhadap tugastugas yang diembannya seperti pada kegiatan belajar mengajar, kegiatan perlombaan, kegiatan ekstrakulikuler siswa yang semuanya melibatkan kinerja guru. Tanggungjawab yang ditunjukkan berupa peranserta aktif, control kegiatan dan tindakan siap ketika terjadi permasalahan.

Penugasa kerja menunjukkan 'ada sedikit kecenderungan' dengan mean 2.65 dikarenakan pembagian tugas yang kurang terstruktur dengan baik melainkan hanya insidental sehingga agak sulit membedakan job description masing-masing penanggungjawab kegiatan. Sedangkan penghargaan terhadap kerja menempati angka terkecil dengan mean 2.05 dengan level 'ada sedikit kecenderungan' yaitu reward dan penghargaan sangat jarang diberikan ketika adanya perjanjian kerja antara kepala sekolah dan guru. Feedback dari hasil kerja yang memuaskan atau terlaksana dengan baik tidak diiringi dengan pemberian penghargaan kepada guru yang bertanggungjawab.

Berdasarkan hasil analisis data serta pembahasan, maka dapat disimpulkan bahwa persepsi para guru SD Negeri di Kecamatan Balung menunjukkan kecenderungan gaya kepemimpinan yang feminine dan transformasional dengan beberapa indicator dari gaya kepemimpinan maskulin dan transaksional yang juga mendukung gaya kepemimpinan feminis dan transformasional.

\section{SIMPULAN}

Persepsi guru sangat penting untuk mengetahui tipe dan gaya kepemimpinan kepala sekolah agar hasil yang diperoleh dapat berfungsi sebagai informasi dan koreksi sehingga terciptanya pembenahan dan kerjasama untuk mencapai visi dan misi sekolah yang telah digagas. Untuk hasil survei dengan indikator yang memiliki nilai minor dapat dinilai tipe kepemimpinan otoriter yang kurang baik dalam kepemimpinan agar dipertahankan dengan mengambil nilai positif dari tipe ini dan meninggalkan nilai negatifnya.Sedangkan tipe kepemimpinan mayor berupa tipe kepemimpinan pribadi yang cenderung dianut oleh kepala sekolah di SD Negeri Kecamatan Balung menunjukkan adanya hubungan kekerabatan yang baik antara pimpinan dan guru sebagai staf pengajar. Namun disisi lain, tipe pribadi juga dapat 
merugikan orang lain yang tidak memiliki kedekatan dengan kepala sekolah sehingga ada baiknya sikap kepala sekolah lebih terbuka.

Hasil penelitian survei ini menunjukkan tipe dominan dari kepemimpinan kepala sekolah perempuan yang 'pribadi' serta gaya kepemimpinan yang 'feminin' dan 'transformasional'. Namun gaya tersebut juga didukung oleh dua indikator yang masing-masing menunjukkan gaya maskulin dan transaksional. Hasil penelitian ini diharapkan untuk memberikan informasi serta gambaran kepemimpinan kepala sekolah perempuan sebagai seorang wanita di SD Negeri Kecamatan Balung yang dapat berguna sebagai bahan refleksi dan koreksi untuk mencapai visi dan misi sekolah. 


\section{DAFTAR PUSTAKA}

Halihah, H. (2015). Kepemimpinan Wanita dalam Manajemen Kependidikan. Jurnal Managemen of Education, 1 (1). 1-9. Diakses 12 Maret 2017 dari jurnal.uinantasari.ac.id/index.php/moe/article/download/341/257

Jelantik, K. (2012). Menjadi Kepala Sekolah yang Profesional. Yogyakarta: Deepublish

Murniati, M. (2008). Manajemen Stratejik: Peran kepala sekolah dalam pemberdayaan. Bandung: Citapustaka Media Perintis

Nathan, A. (2017). Api Kartini dalam Pergerakan Wanita Indonesia Masa Kini. Diakses 12 Maret 2017 dari http://mapcorner.wg.ugm.ac.id/2017/04/api-kartinidalam-pergerakan-wanita-indonesia-masa-kini/

Robbins, S. P. \& Judge, T. A. (2008). Perilaku organisasi. Jakarta: Salemba Empat

Suratman, S. (2017). Kepemimpian Wanita di Indonesia. http://psw.ugm.ac.id/2017/09/18/kepemimpinan-wanita-di-indonesia/

Syuqqah, A. H. A. (1997). Kebebasan Wanita. Jakarta: Gema Insani Press

Timotius, K. H. (2016). Kepemimpinan dan Kepengikutan Teori dan Perkembangannya. Yogyakarta: CV Andi Offset 